\title{
Mobile Phone Use and Communication Model: A Study of Documented Migrant Workers
}

\author{
Amin Shabana ${ }^{1}$, Nani Nurani Muksin ${ }^{2}$, Amin Tohari $^{3}$ \\ \{amin.shabana@umj.ac.id $\left.{ }^{1}\right\}$ \\ Communications Study Programme, Universitas Muhammadiyah Jakarta, Jakarta Indonesia ${ }^{1,2}$ \\ Social Welfare Programme, Universitas Muhammadiyah Jakarta, Jakarta Indonesia ${ }^{3}$
}

\begin{abstract}
Indonesia is one of the biggest countries in sending migrant workers to many destination countries. According to the Malaysian Ministry of Home Affairs report, there were 728,870 or $39 \%$ of Indonesian workers in Malaysia for 2015. Being far away while working, they rely on their cell phones to keep them in touch with their families. Communication via mobile phones is crucial to the social and emotional support of their nuclear families. It is a qualitative study in which at least seventeen migrant workers were interviewed-informants made up of fourteen documented female workers and three documented male workers working in Penang, Malaysia. Snowball sampling technique was used for the selection of informants. All respondents confirmed that their communication to families via mobile phones discusses their day-to-day affairs, financial management, family needs and dreams. Family communication between migrant workers and families is an interactive model of communication. However, all of the informants stated that this communication model was quite expensive and reduced their income. They often bought a free conversation bonus package to solve the problem.
\end{abstract}

Keywords: Indonesian, migrant, workers, remittance, mobile phone

\section{Introduction}

Current era has witnessed a huge scale of international migration. According to the OECD, the total number of migrants exceeded 113 million people. Asian countries provide large numbers of migrants to more than 71 million [1]. More than 6.5 million migrants was from ASEAN countries in 2013. This represents almost 70\% of the total ASEAN migration at the end of the review period [2].

The Indonesian administration ratified the International Convention on the Protection of the Rights of All in 1990. Since then, the country has been one of the largest countries to send migrant workers abroad. Hugo [3] found that Indonesia is a key labor surplus nation and at the end of 2006, an estimated 11 percent of Indonesian workers (11.6 million) were unemployed. This unemployment figure needs to be addressed. Apparently, the government sees that sending more migrant workers could be the solution.

In his study, Chan found that in 2013, Indonesia received USD 7.4 billion in remittances from about six million migrant workers abroad [4]. As a neighboring country, Malaysia is one of destination countries where many Indonesian workers are working to make a living. The National Agency for the Placement and Protection of Migrants (BNP2TKI) was set up on 8 September 2016, with the main task of managing these migration processes as a government representative. 


\subsection{Migrant Worker}

The International Labor Organization (ILO) officially defines a migrant worker as a person who moves from one country to another with a view to being employed [5]. Chan sees that migration is defined in terms of a win-win situation in which migrants, countries of origin and destination, all benefit from cooperation to facilitate transnational temporary migration [4].

UN study in 2011 reported that the estimated number of international migrants increased to 214 million in 2010, with 60 per cent residing in more developed regions, making up 10.3 per cent of the host country population [6]. Meanwhile, the World Bank and the Global Commission on International Migration are optimistic that migrants serve as 'developing agents' and that labor migration is increasingly positive [7].

In the context of Indonesia, Chan's study revealed that the Indonesian administration is part of other neoliberalizing countries that are actively stimulating labor migration as a temporary solution to national unemployment and poverty. Moreover, a long time since the migration representations used by BNP2TKI as a path to sustainable development [4], the new order regime has been encouraging labor migration as a term of "development" since the mid-1980s. In order to facilitate these migration processes, Constable's study indicated that government had issued a licensing regime in 2004. Regimes when not strictly enforced for recruitment agencies. It quickly stimulated the rate of transnational labor migration, especially female migration, which increased dramatically in the aftermath of the 1997 Asian financial crisis [8].

Although Malaysia is not yet a signatory to the International Convention on the Protection of the Rights of All Migrant Workers and Members of Their Families, it remains a popular destination for foreign labor. On the basis of the Malaysian Ministry of Home Affairs report in 2015 , Indonesia is not only the sending country, but also the largest overall number of workers compared to other foreign jobs. There were 728,870 or $39 \%$ of Indonesian workers in Malaysia, followed by Nepal (24\%), Bangladesh (13\%) and Myanmar (7 percent) [5] [9].

Migrant workers in Malaysia are classified as legal (documented) and illegal (undocumented workers. Unfortunately, it is estimated that approximately 60 per cent of illegal migrants are flooding the domestic labor market in Malaysia [9]. Indonesia has to deal with many legal cases caused by a large number of illegal workers in the neighboring country.

As a sending country, Indonesian migrant workers are being dominated by female migrant workers. The number of figures is about $80 \%$ of total worker population. It means remaining number is man migrant workers. More than half of women workers are working in Malaysia and Saudi Arabia. The majority of them come from rural areas with uneducated backgrounds. The situation makes them work in informal sectors, such as domestic workers. Depicting the women workers contribution, people grant them Indonesian as national "heroes". In the meantime, Hamid also found that other migrant workers (including man workers) can be found in a number of sectors such as construction, agriculture, manufacturing, food, electronic, textile, domestic, and entertainment [9].

\subsection{Communication Model}

Wilbur Schramm says communication usually requires about three elements-the resource, this communication plus the desired destination. Ultimately, the original source encodes a communication in addition to direct that to its desired destination via some programmers, in which the message is usually obtained in addition to decoded. Figure 1 shows Shramm's communication model, which is often used as a reference for many communication researchers around the world. 


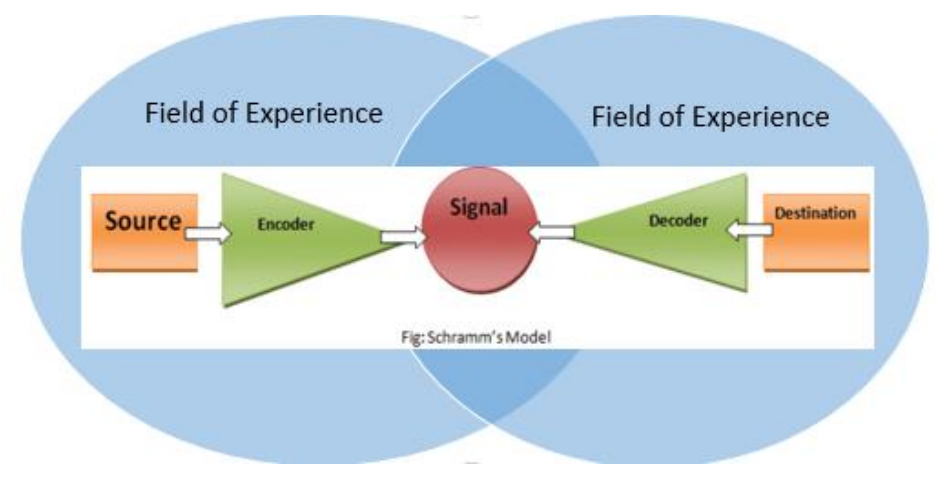

Fig. 1. Schramm's model

\subsection{Mobile Phone Use}

Migrant workers often must deal with human rights cases since the very beginning of their departure in the host country to the destination country. A number of cases showed that the labor's rights prone to be violated by many parties irresponsibly. Therefore, migrant workers must be educated with human rights knowledge. Human rights comprise basic rights belong to all human beings in the world from their birth to death [9]. Besides materialistic rights as compensation for their works, one of basic rights for migrant workers is to keep communicating with their families and peers. Communication is very important to gain social and emotional support from being apart from their beloved ones.

Migrants thank the advancement of communication networks through information and communication technologies (ICTs) which enables them to stay in touch with families in their homeland. The current tool of borderless communication technology attached to migrants' life is mobile phones. There are immense previous studies discuss the use of mobile phones by migrants from different points of view. Most of studies predominantly focus on how mobile phones enable migrants to maintain social support, a sense of closeness and communicate with their distant family members in the host country [6]. Whereas there are many messages discussed during the communication process occurs. One of the possible issues discussed is the use of remittance for any purpose. Unfortunately, there is still a lack of study in analyzing the use of mobile phones of migrant workers in managing remittance with their relatives in the village. This study investigates the difference between man and woman migrant workers' use of mobile phones in managing remittance with their families.

\section{Method}

We investigate gender differences related to the difference between man migrant workers and women migrant workers' use of mobile phones in managing remittance with their families. The study was conducted among Indonesia men and women workers who work in Penang, Malaysia. The total number of informants was 7 workers, consist of 3 men workers and 4 women workers. Woman respondents more than men because the number of woman workers are more than man workers. 
Men respondents are all documented blue-collar workers. Meanwhile, women workers consist of 4 documented blue-collar workers. The informant selection uses snowball sampling contacted for the first stage via Indonesia General Consulate office in Penang, Malaysia. Semistructured interview guides were conveyed to search for informants' perspective on how they use mobile phone in managing the remittance with their families. Throughout the study, ethical procedures were carried out, such as informing respondents that participation was voluntary and they could withdraw from the study at any time. The maps the usage of mobile phones by respondents currently working in Malaysia is presented in Table 1.

Table 1. Mapping of Mobile Phone Use

\begin{tabular}{|c|c|c|c|c|c|c|c|}
\hline \multirow[t]{2}{*}{ Info } & \multicolumn{3}{|c|}{ Man Migrant Workers } & \multicolumn{4}{|c|}{ Woman Migrant Workers } \\
\hline & 1 & 2 & 3 & 4 & 5 & 6 & 7 \\
\hline $\begin{array}{l}\text { How many } \\
\text { mobile phone }\end{array}$ & 1 & 1 & 1 & 1 & 1 & 1 & 1 \\
\hline Provider & $\begin{array}{l}\text { Malaysia' } \\
\text { s provider }\end{array}$ & $\begin{array}{l}\text { Malaysia's } \\
\text { provider }\end{array}$ & $\begin{array}{l}\text { Malaysia's } \\
\text { provider }\end{array}$ & $\begin{array}{l}\text { Malaysia's } \\
\text { provider }\end{array}$ & $\begin{array}{l}\text { Malaysia's } \\
\text { provider }\end{array}$ & $\begin{array}{c}\text { Malaysia's } \\
\text { provider }\end{array}$ & $\begin{array}{l}\text { Malaysia's } \\
\text { provider }\end{array}$ \\
\hline $\begin{array}{l}\text { Family’s } \\
\text { provider }\end{array}$ & $\begin{array}{l}\text { Indonesia' } \\
\text { s provider }\end{array}$ & $\begin{array}{l}\text { Indonesia's } \\
\text { provider }\end{array}$ & $\begin{array}{l}\text { Indonesia's } \\
\text { provider }\end{array}$ & $\begin{array}{l}\text { Indonesia's } \\
\text { provider }\end{array}$ & $\begin{array}{l}\text { Indonesia's } \\
\text { provider }\end{array}$ & $\begin{array}{l}\text { Indonesia's } \\
\text { provider }\end{array}$ & $\begin{array}{c}\text { Indonesia's } \\
\text { provider }\end{array}$ \\
\hline $\begin{array}{l}\text { How often } \\
\text { communicate } \\
\text { with family }\end{array}$ & Weekly & $\begin{array}{l}\text { Weekly- } \\
\text { Biweekly }\end{array}$ & $\begin{array}{l}\text { Weekly- } \\
\text { Biweekly }\end{array}$ & $\begin{array}{c}\text { More than } \\
\text { once a week }\end{array}$ & $\begin{array}{c}\text { Daily, } 3 \\
\text { times a day }\end{array}$ & $\begin{array}{c}\text { More than } \\
\text { once a week }\end{array}$ & $\begin{array}{c}\text { More than } \\
\text { once a week }\end{array}$ \\
\hline $\begin{array}{l}\text { Call or to be } \\
\text { called }\end{array}$ & Call & Call & Call & Call & Call & Call & Call \\
\hline $\begin{array}{l}\text { Who do you } \\
\text { call }\end{array}$ & $\begin{array}{l}\text { Child } \\
\text { Wife } \\
\end{array}$ & Parents & Parents & Parents & 3 children & Parents & Parents \\
\hline $\begin{array}{lr}\text { Phone call/ wa } \\
\text { call/ wa video } \\
\text { call/ } \\
\text { message } & \\
\end{array}$ & Phone call & Phone call & Phone call & $\begin{array}{l}\text { WA video } \\
\text { call }\end{array}$ & $\begin{array}{l}\text { WA video } \\
\text { call }\end{array}$ & Phone call & Phone call \\
\hline $\begin{array}{l}\text { Social media } \\
\text { use }\end{array}$ & $\begin{array}{c}\text { Messange } \\
\text { r } \\
\text { FB }\end{array}$ & FB & FB & FB, WA & & $\mathrm{FB}, \mathrm{IG}$ & $\mathrm{FB}, \mathrm{IG}$ \\
\hline $\begin{array}{l}\text { Active socmed } \\
\text { user? }\end{array}$ & $\begin{array}{l}\text { Weekly } \\
\text { update }\end{array}$ & $\begin{array}{l}\text { Moonthly } \\
\text { update }\end{array}$ & $\begin{array}{l}\text { Weekly } \\
\text { update }\end{array}$ & $\begin{array}{c}\text { More than } \\
\text { once a week }\end{array}$ & $\begin{array}{c}\text { More than } \\
\text { once a week }\end{array}$ & $\begin{array}{c}\text { More than } \\
\text { once a week }\end{array}$ & $\begin{array}{c}\text { More than } \\
\text { once a week }\end{array}$ \\
\hline Reason to call & Caring & Caring & Caring & Caring & Caring & Caring & Caring \\
\hline $\begin{array}{l}\text { Topics of } \\
\text { communication }\end{array}$ & $\begin{array}{l}\text {-Work } \\
\text {-Dreams } \\
\text {-Child }\end{array}$ & $\begin{array}{c}\text {-Work } \\
\text {-daily life }\end{array}$ & $\begin{array}{c}\text { Work } \\
\text { Daily life } \\
\text { Saving } \\
\text { Girl friend } \\
\end{array}$ & $\begin{array}{l}\text { Daily life } \\
\text { Family } \\
\text { needs }\end{array}$ & $\begin{array}{c}\text { Personal } \\
\text { life } \\
\text { Daily needs }\end{array}$ & $\begin{array}{l}\text { Daily life } \\
\text { Dreams } \\
\text { Study }\end{array}$ & $\begin{array}{c}\text { Work } \\
\text { Daily life } \\
\text { Paremts }\end{array}$ \\
\hline $\begin{array}{l}\text { Obstacle of } \\
\text { communication }\end{array}$ & $\begin{array}{l}\text { Network } \\
\text { Costly }\end{array}$ & Costly & $\begin{array}{c}\text { Network } \\
\text { Costly }\end{array}$ & Costly & Costly & Costly & Costly \\
\hline
\end{tabular}

\section{Results and Discussion}

In this category, the researcher wants to find out information related to mobile phone use. These questions aim to answer the second research objective, namely the style of mobile phone use. So that all informants reveal the habits in using the mobile phone as a means of family communication and personal socialization purpose.

The use of mobile phones for migrant workers varies by country and company. Based on previous research in Hong Kong, the use of mobile phones while working is not too strict. In addition to regulations, employers also cannot forbid for fear of being suspected of committing 
human rights violations. Rules in Hong Kong allow migrant workers to sue employers if they are suspectly committing and restricting the rights of migrant workers. The fulfillment of the right to communicate is also considered part of workers' rights.

While in Malaysia, Indonesian migrant workers cannot be as free as in Hong Kong. The weakness of the Indonesian Government's diplomacy, such as in regulating policies regarding migrant workers with the Malaysian Government, makes migrant workers often face various problems. This situation causes companies and employers who employ migrant workers to be more dominant in determining applicable regulations, including the use of mobile phones. All informants shared that they kept their cellphones in the locker while working.

The researcher's initial question to the informant concerns information about the ownership of the cellphone and the choice of provider of the device. This information is essential in order to be able to distinguish how the ownership of Indonesian mobile migrant workers in Penang, Malaysia, who are working under the policies of the government and Malaysian companies. Besides, information about the ownership of telecommunications equipment can also be a marker of the lifestyle of migrant workers in utilizing this rapidly developing information technology.

The second question relates to the communication patterns of each migrant worker and family using a cellphone. The information is intended to describe the depth of long-distance interactions managed by each party. In addition to the intensity, each respondent's answer proves what kind of family communication patterns are established by migrant workers with family members who live far away in their hometown.

The last category of questions is about the use of social media via mobile phones from migrant workers. Like the influence of social media in other community groups, this study wants to explore the extent of the habits of Indonesian migrant workers using social media. Activities using social media for most Indonesians and the world have become a lifestyle. For this reason, it is essential knowing whether this also applies to migrant workers in Penang, Malaysia.

All informants understood enough of the second question component from the researcher. They are enthusiastic about answering every question and answering it smoothly. Shortly, they understand the purpose of the questions from researchers. The absence of rejection from groups of male and female migrant workers makes the process of extracting this information go quite smoothly.

\section{Conclusion}

Based on the communication model from Schramm, family communication that occurs between migrant workers and families is an interactive communication model. First, source, this role can be done by PMI and family. However, in this situation, the initiative often comes from the PMI. They first make the communication, while the family does only in certain urgent situations. Second, encoding, various messages sent are very diverse in the process of communication between PMI and the family. Third, signal, the process of conveying messages from PMI, is channeled through communication media in the form of mobile phones. This technology also bridges the encoding and decoding process in the form of language/text/images/video. Interference also occurs in this communication media during the communication process. Fourth, decoding; is a process of understanding the meaning of messages sent by PMI to the family. Fifth, destination; the family often does this role. Since only the PMI knows the right time to make long-distance communication, the family members 
mostly act as a decoder. Sixth, feedback; despite conducting long-distance communication, but the feedback from the communication that occurs is direct. It is because mobile phone technology allows feedback to be instantaneous or real time, except when the noise occurs in the form of signal interference. Seventh, fields of experience or psychological effects also influence the communication process using this mobile phone. Situations, where PMI works away from family, encourage this moment of communication as a crucial moment. It also provides psychological effects for both parties.

Then, the mapping of mobile phone use concluded as follows. First, migrant workers in Penang who were informants of this study only use 1 mobile phone along with Malaysia's telecommunications provider. Whereas they communicate with family members who use providers from Indonesia. Second, women migrant workers are likely getting more in touch with their families via mobile phones than men migrant workers. Women migrant workers communicate at least once a week, while men migrant workers only once a week or less. However, the initiative to communicate generally comes from migrant workers instead of families. Men migrant workers tend to prefer to communicate by direct phone calls, while women migrant workers are more varied, among others using video call facilities from WhatsApp platform. Third, regarding social media use on mobile phones, women migrant workers are more active than men workers. They use social media every day, while men migrants weekly or even monthly based. Fourth, all respondents stated that communicating with families using a mobile phone as a form of caring for the family. Talks are on daily life, financial management, family needs, and expectations. Nevertheless, each informant stated that such communication bond is a costly activity. To solve the problem, they buy a package top up with a free conversation for a certain time as a bonus. Fifth, male migrant workers communicate via mobile phones to families with a shorter duration of about 5-10 minutes. While female migrant workers tend to communicate more than 10 minutes.

\section{Acknowledgement}

This research received support from the Ministry of Research and Technology of National Agency for Research and Technology, LPPM Universitas Muhammadiyah Jakarta (UMJ), Faculty of Social and Political Sciences UMJ, The National Board for the Placement and Protection of Indonesian Overseas Workers (BP2MI), BP2MI Mataram, BP2MI Cirebon, Migrant Care, SBMI , Indonesia Migrant Workers and all those who contributed to the implementation of the research. 


\section{References}

[1] Jordaan, J. A. (2018). Foreign workers and productivity in an emerging economy: The case of Malaysia. Review of Development Economics. https://doi.org/10.1111/rode.12334

[2] Tuccio, M. (2017). Determinants of Intra-ASEAN migration. Asian Development Review. https://doi.org/10.1162/ADEV_a_00084

[3] Budijanto, Wan Ahmad, W. I., \& Komang Astina, I. (2015). Level of economic prosperity, social status and comfortable living of migrant workers in Tulungagung District, Indonesia. Mediterranean Journal of Social Sciences. https://doi.org/10.5901/mjss.2015.v6n3s2p282

[4] Chan, C. (2014). Gendered morality and development narratives: The case of female labor migration from Indonesia. Sustainability (Switzerland). https://doi.org/10.3390/su6106949

[5] Loganathan, T., Rui, D., Ng, C.-W., \& Pocock, N. S. (2019). Breaking down the barriers: Understanding migrant workers' access to healthcare in Malaysia. PLOS ONE. https://doi.org/10.1371/journal.pone.0218669

[6] Chib, A., Wilkin, H., \& Hua, S. (2013). International migrant workers' use of mobile phones to seek social support in Singapore. Information Technologies \& International Development.

[7] Faist, Thomas. 2008. Migrants as transnational development agents: an inquiry into the newest round of the migration-development nexus. Population, Space and Place 14, 21-42. DOI: 10.1002/psp.471

[8] Constable, N. (2015). Migrant motherhood, "failed migration", and the gendered risks of precarious Labour. TRaNS: Trans-Regional and -National Studies of Southeast Asia. https://doi.org/10.1017/trn.2014.13

[9] Ab Hamid, Z., Shukor, S. F. A., \& Ali Mohamed, A. A. (2018). Rights of migrant workers under Malaysian employment law. Journal of East Asia and International Law. https://doi.org/10.14330/jeail.2018.11.2.05 